\title{
Black Pigmentation of Terminal Ileum after Long Term Ingestion of Charcoal
}

\author{
Jun Young Lee, Sung Bum Kim, Sang Hoon Lee, Hee Jung Moon, Jae Won Choi, \\ Jong Ryul Eun, Byung Ik Jang, Tae Nyeun Kim, Joon Hyuk Choi* \\ Department of Internal Medicine and *Department of Pathology, \\ College of Medicine, Yeungnam University, Daegu, Korea
}

\begin{abstract}
-Abstract-
Isolated pigmentation of the terminal ileum is rare incidental finding when performing a colonoscopic examination. The common substances that cause gastrointestinal pigmentations are lipofuscin, iron sulphide(FeS), hemosiderin, and other exogenous materials such as silicates and titanium. In most cases, pigmentation of the terminal ileum has no subjective symptoms, so it is found in autopsy or incidental colonoscopic examination. The cause of pigmentation has not been clearly identified. We experienced a case of pigmentation of terminal ileum associated with long term charcoal ingestion. This finding supports that the source of ileal pigmentation is ingested material.
\end{abstract}

Key Words : Colonoscopy, Ileum, Pigmentation, Charcoal

Introduction

Melanosis ilei is defined when the brownishblack or black colored pigmentations are presented in terminal ileum ${ }^{1)}$. It can be divided to two groups. One is combined with the melanosis coli, and the other is isolated pigmentation of the terminal ileum without colonic involvement ${ }^{2)}$. The melanosis means that the pigment material is not melanin but dark $^{3)}$.

Isolated pigmentation of the terminal ileum is rare incidental finding when performing a colonoscopic examination or an autopsy study ${ }^{1)}$. The common substances that cause gastrointestinal pigmentations are lipofuscin, iron sulphide(FeS), hemosiderin, and other exogenous materials such as silicates and

책임저자 : 장병익, 대구광역시 남구 대명동 317번지, 영남대학교 의과대학 내과학교실

Tel: (053) 620-3831, Fax: (053) 654-8386, E-mail: jbi@med.yu.ac.kr 
- Jun Young Lee $\cdot$ Sung Bum Kim $\cdot$ Sang Hoon Lee $\cdot$ Hee Jung Moon $\cdot$ Jae Won Choi

Jong Ryul Eun $\cdot$ Byung Ik Jang $\cdot$ Tae Nyeun Kim $\cdot$ Joon Hyuk Choi -

titanium. Urbanski et $\mathrm{al}^{4)}$ reported that the pigment granules were located in the macrophages of the submucosa and lamina propria. The possible mechanism that causes this pigmentation is not fully understood.

Melanosis coli is a common finding when performing a colonoscopic examination, but melanosis ilei is rare. We experienced a case of isolated terminal ileal pigmentation that was associated with long term charcoal ingestion.

\section{Case report}

A 45-year-old female visited our gastroenterology department due to lower abdominal discomfort and irregular bowel habits that she experienced for 1 month. She had no specific medical or psychic disease and had taken a powdered type of charcoal, about $500 \mathrm{mg}$ at a month, during the past 2 years for promoting her health. She denied smoking or any history of alcohol consumption and herbal medication.

Her vital signs were stable and the physical examination showed no abnormal features. She underwent colonosocopic examination, and the exam showed no specific findings in the colon, but there was a well demarcated black or grayish-black colored geographic pigmentation on the terminal ileum (Fig. 1). Histologic examination of this lesion showed lymphoid hyperplasia and black pigmentation at the submucosal layer (Fig. 2). This pigmentation was observed in the cytoplasm of macrophage and it was not stained by Prussian blue and Fontanna Masson.

\section{Discussion}

Melanosis ilei is characterized by gross greyish-black or brownish-black pigmentation of the mucosa of the terminal ileum. There were several substances that cause gastrointestinal tract pigmentation. They were lipofuscin, iron sulphide, hemosiderin and exogenous material such as silicates and titanium.

In many studies, the materials causing melanosis coli were analysed. At first, lipofuscin was the pigmentation material of melanosis coli in humans. Iron sulphide was found in duodenal melanosis ${ }^{4)}$, and hemosiderin in melanosis ilei ${ }^{1}$. In general, melanosis ilei had no clinical symptoms, and was found in autopsy $^{3)}$.

In contrast of melanosis coli, the cause of pigmentation of the terminal ileum has not been clearly identified. Urbanski et $\mathrm{al}^{4)}$ reported on pigment granules of terminal ileum that were similar to those found in pulmonary macrophages via electron probe X-ray analysis. They showed that this material was exogenous, but it was not clear if the origin of the pigmentation was hematogenous spread from the lung or it was directly from ingested material.

Charcoal is the blackish residue consisting of impure carbon obtained by removing 
water and other volatile constituents from animal and vegetation substances. It consists of minute particles which can adsorb protein particles, lipid droplets and other toxic agents. So it can be used in gas purification, gold purification, metal extraction, water purification, medicine, sewage treatment, air filters in gas masks and filter masks, filters in compressed air and many other applications. In case of the charcoal ingestion of humans, it absorbs the toxic materials and impurities rapidly in a minute ${ }^{6)}$, so it is often used as a purpose of health promotion.

Carboneous material is a common deposit in human tissue. Khan ${ }^{5}$ reported a case of coal dust deposition of the esophagus. In that case, the pigment of the esophagus was usually located in the macrophages.

In our case, long term charcoal ingestion was the possible cause of the patient's ileal pigmentation. We suggest that the source of the terminal ileal pigmentation was ingested material and then it entered into the macrophages by phagocytosis. We presumed the stasis of material in the terminal ileum helped to cause the pigmentation.

Won and Ramchand ${ }^{2)}$ reported the first case of isolated ileal pigmentation in an 85year-old male with right colon obstruction, which was due to cancer. Ghadially et $\mathrm{al}^{1)}$ reported a case of haemosiderosis ilei, and they assumed that the cause was chronic GI bleeding.

Melanosis ilei was not a clinical manifes- tation, but in our case, it presented from chronically ingested charcoal. The endoscopic findings and histologic features are enough to diagnose the melanosis ilei, but the treatment and prognosis are not yet established. Further studies are required concerning the relation between clinical disease and ileal pigmentation.

\section{요 약}

솣은 흡착하는 성질이 있어 급성 약물 중독 시 중화제로 사용되며 일부는 건강식품으로서 복용되고 있다. 회장흑색증은 회장말단부 점막 에 육안적으로 회흑색 혹은 회갈색의 색소 침 착으로 정의되며 특이한 임상증상이 없어 대부 분 대장내시경 검사시 우연히 발견되거나 부검 시에 발견된다. 저자들은 장기적으로 숯 복용 한 환자의 대장내시경 검사 상 숯 복용이 원인 으로 추정되는 회장 말단의 병변을 관찰하였기 에 이에 보고하는 바이다.

45세 여자환자로 한 달간의 하복부 불편감 과 불규칙한 배변을 주소로 내원하였다. 환자 는 과거력상 특별한 질환은 없었고 2 년여 전부 터 건강 증진을 목적으로 분말형의 솣가루를 한달에 $500 \mathrm{mg}$ 정도 복용하고 있었다. 내원 시 환자의 활력징후는 안정적이었으며 이학적 검 사상 특이한 소견은 없었다. 환자는 대장내시 경을 시행하였고 검사상 대장에는 특이한 병변 이 없었고, 회맹판에서 $10 \mathrm{~cm}$ 까지 회장 말단에 주변과 경계가 분명한 첩포모양의 흑색소 침착 이 관찰되었다. 조직 검사상 림프과다형성과 흑색소 침착이 관찰되었다.

문헌 조사상 장기간의 숫복용에 따른 대장 내시경상의 변화와 회장 말단 부분의 흑색소 
- Jun Young Lee $\cdot$ Sung Bum Kim $\cdot$ Sang Hoon Lee $\cdot$ Hee Jung Moon $\cdot$ Jae Won Choi $\cdot$ Jong Ryul Eun • Byung Ik Jang • Tae Nyeun Kim • Joon Hyuk Choi -

침착에 대한 보고는 찾아보기 힘들며 회장 말 단의 병변이 숯복용에 따른 변화로 추정되므로 이에 보고하는 바이다.

\section{References}

1. Ghadially FN, Boone SA, Walley VM. Melanosis (haemosiderosis) ilei. J Submicrosc Cytol Pathol 1994;26:461-5.

2. Won KH, Ramchand S. Melanosis of the ileum. Case report and electron microscopic study. Am J Dig Dis 1970;15:57-64.
3. Ghadially FN, Walley VM. Melanoses of the gastrointestinal tract. Histopathology 1994;25: 197-207.

4. Urbanski SJ, Arsenault AL, Green FH, Haber G. Pigment resembling atmospheric dust in Peyer's patches. Mod Pathol 1989;2:222-6.

5. Khan HA. Coal dust deposition-rare cause of "black esophagus". Am J Gastroenterol 1996; 91:2256.

6. David OC. Actvated Charcoal: Antidote, Remedy, and Health Aid. New York: TEACH publishers; 1980 p.33. 